Ks. Janusz LEWANDOWICZ

(Łódź, WSD)

\title{
WYBORY BISKUPÓW W ŚWIETLE KORESPONDENCJI GRZEGORZA WIELKIEGO
}

Pontyfikat Grzegorza Wielkiego przypadł na czas zmagania się Kościoła na Zachodzie z trudnościami wynikającymi z konieczności odnajdywania się w sytuacji rosnącego naporu Longobardów. Prócz tego na północy i zachodzie umacniało się i krzepło frankońskie panowanie. Czas tych dynamicznych zmian w życiu społecznym i politycznym był okresem, w którym trudno byłoby sobie wyobrazić kierowanie społecznością świecką bez udziału biskupów: dotyczyło to nie tylko terenów związanych z cesarstwem, gdzie ich znaczenie od czasów Konstantyna nieustannie rosło. Pomoc doświadczonej administracji kościelnej mogła być szczególnie cenna w nowych królestwach franków. Właśnie biskupi jako przywódcy wspólnot religijnych w tych „szczególnie trudnych czasach” (według określenia Grzegorza z Tours) byli koniecznym wsparciem dla tamtejszych królów ${ }^{1}$ i pewnego rodzaju fundamentem stabilizacji. Taka pozycja rządców Kościoła mogła być kusząca i bez wątpienia prowokowała napięcia, kiedy należało uwzględniać nie tylko duchowy wymiar ich posługi.

Korespondencja (848 zachowanych listów w 14 księgach) pozostawiona przez Grzegorza Wielkiego ${ }^{2}$ jasno pokazuje, że wybór biskupa był dla niego najistotniejszym aktem z punktu widzenia działalności kościelnej. Jest to zrozumiałe zważywszy, jak wielkie znaczenie od czasu uznania chrześcijaństwa za religię cesarstwa urząd ów zyskał. Nie tylko jednak względy związane ze sprawowaniem władzy administracyjnej, w tych niezwykle trudnych dla cesarstwa i papiestwa czasach, decydowały o wadze, jaką przykładał Grzegorz do obsadzania stolic biskupich właściwymi ludźmi. Głównym motywem jego działania była troska o kształt życia duchowego. Istotny wpływ na nie z racji na swe kierownicze stanowiska w Kościele mieli właśnie biskupi. Poniższy tekst ma za zadanie ukazać działania papieża w odniesieniu do obsadzania stolic biskupich, właśnie w kontekście troski o duchowy wymiar życia Kościoła.

\footnotetext{
${ }^{1}$ Por. R.A. Markus, Grzegorz Wielki, przełożył P. Nehring, Warszawa 2003, 205.

${ }^{2}$ Por. Gregorius Magnus, Registrum epistolarum, PL 77, 441-1328; ed.P. Ewald-L.M. Hartmann, MGHEpist 1-2, Berlin 1891-1899; ed. D. Norberg, CCL 140-141A, Turnholti 1982 (tym wydaniem się posługuję), tłum. J. Czuj: Św. Grzegorz Wielki, Listy, I-IV, Warszawa 1954-1955.
} 
Z korespondencji papieża wynika, że dla zapewnienia właściwego poziomu owego życia duchowego uważał, że do posługi biskupiej należało powoływać jedynie osoby wypróbowane, przez co należało rozumieć ludzi ,starszych wiekiem i o czystych obyczajach"3. Stosownym i koniecznym sprawdzianem, według Grzegorza, był czas posługi na urzędzie prezbitera. Papież nie dopuszczał możliwości, aby biskupem mógł zostać obrany ktoś, kto nie był wcześniej duchownym: ze względu na niebezpieczeństwo ubiegania się o godność biskupią człowieka pragnącego władzy w rozumieniu świeckim, papież nie zezwalał czynić odstępstw od wspomnianej zasady, co zresztą ukazuje procedura obsadzania stolicy wakującej po śmierci biskupa. Pierwszy krok w takim przypadku, według praktyki kształtowanej przez Grzegorza, należał do wizytatora. Jego zadaniem było zatroszczenie się, aby mieszkańcy pozbawionej pasterza stolicy „ubiegali się” (expetant ${ }^{4}$ ) o takiego biskupa, który byłby godny urzędu a kanony nie stały na przeszkodzie jego wyborowi. Zgodność wspólnoty, co do kandydata, nie oznaczała automatycznie, iż mógł on objąć stolicę. Papież rezerwował sobie w każdym przypadku prawo zatwierdzania wyboru. Było to wprawdzie zadanie, do wypełniania którego, według postanowienia Soboru Nicejskiego, powołany był metropolita: od jego aprobaty uzależniał sobór objęcie urzędu biskupiego ${ }^{5}$. Grzegorz starał się jednak kontrolować obsadzanie stolic biskupich głównie w ramach metropolii związanej z Rzymem. Stąd też $\mathrm{w}$ jego listach znajdujemy stosowaną w kancelarii papieskiej formułę, w której używano, w odniesieniu do wybranego kandydata, terminu ,postulatus” - „ten, o którego proszą"6. Należy w takim przypadku rozróżnić pomiędzy wyborem (electio), a prośbą (postulatio) o zatwierdzenie biskupa.

To że papież rezerwował sobie prawo decydowania o obsadzeniu stolicy, nie oznaczało, iż dążył do tego, aby mieć wyłączny głos w sprawie obsadzania biskupstw. Ustalona już wówczas tradycja kanoniczna domagała się zgody na biskupa ze strony wspólnoty. Kanony, na które powołuje się sam Grzegorz, wykluczały możliwość ustanowienia takiego biskupa, któremu sprzeciwiałaby się wspólnota ${ }^{7}$. Inne wymagane kwalifikacje miały zapewnić odpowiedni moralno-

\footnotetext{
${ }^{3}$ Por. np. Epistula (ad Adeodatum) III 48, CCL 140, 193, Czuj I 224-226.

${ }^{4}$ Formuła używana w korespondencji przez kancelarię Grzegorza była właściwie stała, por. Epistula XIII 14, CCL 140A, 1014: „Et ideo dilectio tua ad praedictam Ecclesiam ire properabit, et assiduis adhortationibus clerum plebemque eiusdem Ecclesiae admonere festinet, ut, remoto studio, uno eodemque consensu talem sibi praeficiendum expetant sacerdotem, qui et tanto ministerio dignus valeat reperiri, et a venerandis canonibus nullatenus respuatur"; zob. też II 22; II 32; II 33; IV 39; V 22; VI 21; VII 16; IX 81, 82, 101, 140, 141 i 185; XIII 14, 15 i 19.

${ }^{5}$ Por. Concilium Nicaenum can. 6, ŹMT 24 (= DSP I), Kraków 2001, 30-33.

${ }^{6}$ Por. Epistulae II 32 i 33; IV 39; V 22; VII 16; IX 82, 101, 140 i 186; XIII 14 i 18.

${ }^{7}$ Por. Coelestinus, Epistula (ad episcopos provinciae Viennensis) 4, 5, PL 50, 434B: „Nullus invitis detur episcopus. Cleri, plebis et ordinis, consensus ac desiderium requiratur"; Leo I, Epistula 67, 4, PL, 54, 771D: „Ut nullus invitis ordinetur episcopus. Cum ergo de summi sacerdotis electione tractabitur, ille omnibus praeponatur quem cleri plebisque consensus concorditer postularint, ita ut
} 
intelektualny poziom kandydatów ${ }^{8}$. Wspomniana wyżej tradycja ${ }^{9}$ nie dopuszczała do ich grona m.in. świeżo nawróconych (to znaczy przed upływem roku), tych, którzy nie ukończyli jeszcze trzydziestu lat życia, należących do dworu cesarskiego i sprawujących władzę świecką. Ponadto nie byli dopuszczani do tej godności obciążeni zarzutem przestępstwa, neofici, mający defekty fizyczne, dwakroć żonaci ${ }^{10}$, oraz nie znający kanonów i psalmów ${ }^{11}$; od kandydata wymagano także pewnego doświadczenia.

Tradycja formułowała jednocześnie pozytywne wymogi stawiane kandydatom. Przepisy, mówiące o koniecznych walorach wymaganych u biskupa, zawierały także świeckie Novellae Justyniana (527-565). W czwartej z nich znajdujemy następujący passus:

„Uznajemy, że można święcić ludzi cieszących się dobrą opinią, umiejących czytać i pisać, i wykształconych (niepiśmiennych w ogóle nie chcemy, żeby nie wchodzili do stanu duchownego żadnego stopnia, to znaczy prezbiterów i diakonów, podobnie jak i nie umiejących odmawiać modlitwy święte jak i czytać księgi kanonów kościelnych), i takich, którzy przyjmują święcenia bez zarzutu, nienagannie i bez żadnego sprzeciwu, jak też bez dawania jakichkolwiek pieniędzy lub rzeczy"12;

si in aliam forte personam partium se vota diviserint, metropolitani iudicio is alteri praeferatur qui maioribus et studiis iuvatur et meritis: tantum ut nullus invitis et non petentibus ordinetur, ne plebs invita episcopum non optatum aut contemnat aut oderit, et fiat minus religiosa quam convenit, cui non licuerit habere quem voluit".

${ }^{8}$ Por. Gregorius Magnus, Epistula II 6, PL 77, 543C, n. h, zob. niżej nota 9.

${ }^{9}$ Por. Constitutiones Apostolorum VIII 47, 80, ŹMT 42, 291. Najstarsze przepisy znajdujemy w liście do biskupa Hilariusza przypisywanym papieżowi Stefanowi I (254-257), zob. Epistula Stephani papae (ad Hilarium episcopum) 1, PL 3, 999B-1000B. Kryteria negatywne por. Gregorius Magnus, Epistula II 6, PL 77, 543C, n. h: „Respuuntur laici ante anni conversionem, respuuntur $\mathrm{XXX}$ annos nondum adepti, respuuntur curiales, et qui saecularem gesserunt potestatem, respuuntur criminosi, neophyti, inviti, digami, qui corpore vitiati, qui imperiti, ignorantes canones, psalmos, et ex Turonensi III, et Cabillon. II, librum pastoralem sancti Gregorii; illegitimi, schismatici, etc."; por. też Justiniani Novella 6, PL 72, 934D: „Neque autem eos volumus omnino, qui officiales aut curiales constituti sunt, suscipere ordinationem, nisi secundum leges, quas super his superius posuimus pridem, quas et hic nunc confirmamus".

${ }^{10}$ Por. Constitutiones Apostolorum VIII 47, 17-18, ŹMT 42, 276-277; zob. też Siricius, Epistola ad Himerium episcopum Tarraconensem 8, 12, PL 13, 1141A-B.

${ }^{11}$ Por. np. Gregorius Magnus, Epistula V 51 i XIV 11, CCL 140, 345 i CCL 140A, 1080-1081. Ostatecznie II sobór w Nicei określił w kan. 2 znajomość całego psałterza jako warunek niezbędny do uzyskania godności biskupiej, zob. Concilium Nicaenum II (787) can. 2, ŹMT 24, 344-345.

12 Justiniani Novella 6, PL 72, 934D: „... et boni testimonii viros ordinari sancimus, litteras omnino scientes, et eruditos constitutos (litteras enim igorantes omnino nolumus, neque unum ordinem suscipere clericorum, videlicet presbyterorum et diaconorum, tam sacras orationes dicentium quam ecclesiarum et canonum legentium libros), et ordinationem sine querela, et inculpabilem, et sine aliqua contradictione, et sine datione pecuniarum aut rerum suscipientes. Neque autem eos volumus omnino, qui officiales aut curiales constituti sunt, suscipere ordinationem, nisi secundum leges, quas super his superius posuimus pridem, quas et hic nunc confirmamus". 
podobne zastrzeżenia dotyczyły tych, którzy dawali pieniądze na lichwę ${ }^{13}$.

Istotnymi warunkami, z punktu widzenia samego Grzegorza, jakie winny być postawione kandydatowi na biskupa, były nie tylko znajomość Pisma Świętego ${ }^{14}$ oraz gorliwość w wypełnianiu zadań kościelnych - należące do podstawowych wymogów ${ }^{15}$. Ważna była także równowaga duchowa, pozwalająca na zachowanie wewnętrznej harmonii w sytuacji zmiany sposobu działania, uzależnionej od pełnienia posługi biskupiej. Sam doświadczywszy wielu roztargnień związanych z potrzebą sprostania znacznie większej ilości problemów, z jakimi musiał się zmierzyć po wyborze na papieża, o czym z bólem pisze w liście do swego przyjaciela, biskupa Leandra z Hiszpanii ${ }^{16}$, dostrzegał konieczność znalezienia takiego kandydata, który będzie się mógł oprzeć niebezpieczeństwom związanym z pełnieniem tej posługi ${ }^{17}$.

Papież musiał decydować w delikatnej i trudnej materii, zwłaszcza jeśli uwzględnić wymagania stawiane przez Kościół kandydatom na biskupów. Sto lat wcześniej synod w Kartaginie określał je jednoznacznie:

„Gdy trzeba wyświęcić biskupa, należy najpierw zbadać, czy ma zdrowy rozsądek, czy zdolny jest do przyjęcia nauki, czy ma zrównoważone obyczaje, czy prowadzi czyste życie, czy jest trzeźwy, czy pilnuje swoich obowiązków, czy jest pokorny, czy jest przystępny, czy miłosierny, czy umie czytać, czy silny mocą prawa Pańskiego, czy wrażliwy na ducha Pism, czy biegły w kościelnych postanowieniach, a przede wszystkim, czy przystępnie objaśnia prawdy wiary"18.

Spełnienie wszystkich tych warunków w czasach Grzegorza było niezwykle trudne.

${ }^{13}$ Por. Gregorius Magnus, Epistula X 19, CCL 140A, 848-849, Czuj IV 27.

${ }^{14}$ Wyrazem tego była stosowana już wówczas praktyka liturgiczna podczas święceń biskupich. W czasie obrzędu dwaj biskupi umieszczali i trzymali na głowie i karku konsekrowanego księgę Ewangelii, por. Concilium Carthaginense IV (486), can. 2, CCL 149, 344: „Episcopus cum ordinatur, duo episcopi ponant et teneant Evangeliorum codicem super caput et cervicem eius, et uno super cum fundentem benedictionem, reliqui episcopi omnes qui adsunt manibus suis caput eius tangant”.

${ }^{15}$ Podkreśla to Grzegorz w liście do patrycjusza Wenancjusza, któremu dziękuje równocześnie za wskazanie opata Urbika jako potencjalnego biskupa. Z listu tego wynika jednak, że papież albo uznał, iż dobrze prowadzone życie mnisze zasługuje na ocalenie w jego dotychczasowym kształcie niezależnie od okoliczności albo też wykorzystał pochwałę dla subtelnej odmowy mając wątpliwości, co do siły osobowości opata, por. Epistula XIII 12 (14), CCL 140A, 1011-1013, Czuj IV 181-183.

${ }^{16}$ Por. Epistula I 41, CCL 140, 47-49, Czuj I 65-67.

${ }^{17}$ Por. tamże XIII 12 (14), CCL 140A, 1011-1013, Czuj IV 181-183.

${ }^{18}$ Concilium Carthaginiense IV (486) can. 1, ed. C. Munier, CCL 149, 343: „Qui episcopus ordinandus est antea examinetur; igitur si natura prudens est, si docibilis, si moribus temperatus, si vita castus, si sobrius, si semper suis negotiis, si hominibus affabilis, si misericors, si litteratus, si in lege Domini instructus, si in scripturarum sensibus cautus, si in dogmatibus ecclesiasticis exercitatus, et ante omnia si fidei documenta verbis simplicibus asserat". 
Z listów wyraźnie wynika, iż prawo wyboru należało zarówno do duchowieństwa (clerici), jak i do pochodzących ze szlachetnych rodów (ordo), sprawujących funkcje publiczne, aż po zwykły lud (plebs) ${ }^{19}$. Od wyborców wymagał, aby nie kierowali się własnymi korzyściami, lecz dobrem Kościoła, realizowanym przez wybór kandydata odznaczającego się cechami, które starał się im przedstawiać w swoich listach ${ }^{20}$.

Ostateczna decyzja, co do kandydata, mogła zależeć od tego, czy wybór został dokonany jednomyślnie. Jeśli tak nie było, papież zasięgał opinii na temat kandydatów. Na przykładzie diakona Krescensa widać, jakie kwalifikacje dotyczące życia były istotne z punktu widzenia papieża. Stawia on pytanie o to, jak wypełniał swoje dotychczasowe obowiązki przełożonego domu gościnnego; nakazuje też zbadać dokładnie jego życie, obyczaje i postępowanie. Dopiero wówczas, gdy okaże się bez zarzutu, pozwala zabiegać o jego zatwierdzenie. W tym samym liście jako kryteria wskazuje również troskliwość o zewnętrzne korzyści wiernych, ponadto wymienia takie cnoty, jak pokora z uczciwością, powaga z miłością, cnota czystości oraz przykład życia ${ }^{21}$.

Wpływ na wybór biskupa mógł mieć również sam cesarz. Wydaje się jednak, że imperatorzy przejawiali tego rodzaju zainteresowanie jedynie w odniesieniu do stolic pozostających wprawdzie pod jurysdykcją papieża, ale związanych ze wschodnią częścią cesarstwa, jak na przykład Salona w Dalmacjii22 czy Prima Iustiniana w Dardanii ${ }^{23}$.

Bliskość stolicy cesarskiej i oddalenie od Rzymu w naturalny sposób sprzyjało osłabieniu wpływów papieskich. Widoczne było to wyraźnie, kiedy cesarz Maurycjusz skorzystał z nadarzającej się sposobności po śmierci biskupa Salony Natalisa ${ }^{24}$, aby obsadzić wakującą tam stolicę: uczynił to bez wiedzy papieża wprowadzając swego protegowanego Maksymusa. Grzegorz powoływał się w tym przypadku na zasady, które wymagały, aby nie dopuszczać do urzędów kościelnych ludzi niegodnych czy nieodpowiednich, do których należeli, jak wspomnieliśmy, również ludzie związani z dworem. O tym, jak długo walczył papież ze skutkami cesarskiej decyzji, podjętej bez uzgodnienia z Grzegorzem, świadczy obfitość korespondencji zachowanej w sprawie Maksymusa.

Na przykładzie Salony widać, że papieżowi zależało na autonomii miejscowej społeczności w sprawie wyboru biskupa, jeżeli godność kandydata nie budziła zastrzeżeń. Oczywiście zachowywanie tej autonomii mogło w tym przypadku służyć wzmocnieniu wpływu papieża na obsadzanie stolicy. Należało jednak czuwać, aby ludzie niepowołani nie mieli możliwości negatywnego wpływu na wybór. Tymczasem powód do obawy z powodu poten-

\footnotetext{
${ }^{19}$ Por. np. Epistulae II 3; III 13, 15, 22 i 26; V 21.

${ }^{20}$ Por. tamże III 29 i V 54.

${ }^{21}$ Por. Epistula XIII 12 (14), CCL 140A, 1011-1013, Czuj IV 181-183.

${ }^{22}$ Por. tamże IV 20.

${ }^{23}$ Por. tamże V 10 i 16.

${ }^{24}$ Por. tamże III 22.
} 
cjalnego oddziaływania na układ sił w Salonie dawał niejaki Malchus, były zarządca majątku papieskiego w Dalmacji. Był on biskupem, który został złożony z urzędu prawdopodobnie za nadużycia finansowe ${ }^{25}$. Mimo iż przebywał już wówczas na Sycylii, papież obawiając się jego wpływu zakazał mu mieszać się w wybór biskupa. Jednocześnie nakazał ówczesnemu zarządcy, subdiakonowi Antoninowi, czuwanie nad prawidłowym i jednomyślnym wyborem biskupa. Szczególnie miał dbać o to, aby wybór nie był dokonywany przy jakiejkolwiek protekcji oraz z uniknięciem możliwości kupowania urzędu w jakiejkolwiek formie ${ }^{26}$. Być może była to realna obawa związana z osobą wspomnianego Malchusa, który był zwolennikiem Maksymusa, osadzonego na stolicy w Salonie wbrew woli Grzegorza ${ }^{27}$.

Przebieg zdarzeń, związanych z objęciem stolicy przez Maksymusa, świadczy o tym, że wpływ papieża na wybór kandydatów bywał ograniczony zwłaszcza tam, gdzie w grę wchodziło zainteresowanie ze strony cesarza obsadzeniem własnego człowieka; nie pomagały uprzednie działania ani gwałtowna reakcja papieża. Jego postawa wskazuje jednak jednoznacznie na dążenie do zachowania niezależności wyboru kandydata, o ile jest on umotywowany rzeczywistym dobrem Kościoła.

Według przyjętych norm, wyboru trzeba było dokonać spośród miejscowego duchowieństwa ${ }^{28}$. W przypadku braku kandydata spełniającego wymagane kryteria, należało go poszukać w Kościołach sąsiednich. Zwracano się wówczas do tamtejszego biskupa z prośbą o wyrażenie zgody na odejście takiego kandydata $z$ szeregów miejscowego duchowieństwa ${ }^{29}$. W ten sposób wszczynano procedurę przejścia duchownego do innej diecezji. Wymagało ono jednak zgody jego biskupa w postaci tzw. „litterae dimissoriae” ( $\alpha \pi \circ \lambda v \tau \imath \kappa \alpha i ~ \gamma \rho \alpha \varphi \alpha i)$ ), zwane

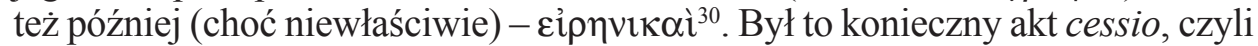
procedury odstąpienia duchownego innemu Kościołowi ${ }^{31}$. Gdyby zaś nie było możliwości wyszukania odpowiedniego duchownego w diecezjach sąsiednich,

${ }^{25} \mathrm{Na}$ stanowisku zarządcy majątku kościelnego, por. tamże III 22 i V 6.

${ }^{26}$ Por. tamże III 22.

${ }^{27}$ Nagła śmierć Malchusa w Rzymie, po tym jak został wezwany do zdania rachunków z włodarstwa w Dalmacji, a następnie skazany, jak utrzymuje Grzegorz, nawet bez jego wiedzy, stała się później okazją dla Maksymusa, aby dla umocnienia swojego stanowiska na dworze przeciwko papieżowi, rozsiewać w Konstantynopolu wieści, iż Malchus został osadzony przez papieża W więzieniu a następnie zamordowany za pieniądze, por. tamże V 6.

${ }^{28}$ Por. Gregorius Magnus, Epistula II 22, CCL 140, 108-109. O tym, iż była to utrwalona zasada, świadczy częste odwoływanie się do formuły powielanej przez kopistów, zob. np. Epistulae II 32; VII 16; IX 81; IX 185; XIII 12, 14 i 19. Odnośne normy znajdują się już w postanowieniach synodu w Kartaginie z 254 r., por. Cyprianus Carthaginensis, Epistula 67, 5, ŹMT 37, Kraków 2006, 18.

${ }^{29}$ Por. Gregorius Magnus, Epistula XIV 11, CCL 140A, 1080-1081.

${ }^{30}$ Por. Zonaras, Lexicon 633, ed. J.A.H. Tittmann: Iohannis Zonarae lexicon ex tribus codicibus manuscriptis, I, Leipzig 1808 (repr. Amsterdam 1967), 633; zob. np. Concilium Carthaginiense (348) can. 7.

${ }^{31}$ Por. Gregorius Magnus, Epistulae I 81; V 20; VI 20. 
papież zalecał szukać właściwego kandydata wśród duchowieństwa rzymskie$\mathrm{go}^{32}$. Dawało to niewątpliwie możliwość jeszcze ściślejszego wiązania kościołów lokalnych z Rzymem, nie można w tym jednak widzieć jakiejś tendencji uzależniania się od niego, gdyż korzystanie z takiego rozwiązania występowało rzadko i nie widać szczególnego dążenia do jego narzucania.

Papież wykorzystywał jednak okazje, aby w subtelny sposób budować zwarty, skupiony wokół Rzymu episkopat. Dowodzi tego m.in. sprawa sukcesji w Mediolanie po śmierci biskupa Laurencjusza, zmarłego w Genui 21 sierpnia 592 roku. Biskup Laurencjusz wraz z częścią duchowieństwa opuścił wcześniej Mediolan ze względu na niebezpieczeństwo ze strony Longobardów. Po jego śmierci papież miał otrzymać list informujący o wyborze Konstancjusza (którego popierał), dokonanym rzekomo w Mediolanie przez pozostałą tam część duchowieństwa; list ten jednak nie zawierał żadnego podpisu ${ }^{33}$. Można z dużym prawdopodobieństwem przyjąc hipotezę, którą stawia Robert Austin Markus $^{34}$, że wybór został faktycznie dokonany w Genui ${ }^{35}$, gdzie nie było niechętnego nastawienia do Grzegorza, ani popieranej przez Longobardów opozycji związanej ze schizmą wynikłą ze sporu o „Trzy Rozdziały”36. Nie zajęta jeszcze przez nich Genua była o wiele bardziej, niż Mediolan, przychylnym środowiskiem dla wyboru człowieka, o którym sam Grzegorz w liście pisał, że łączą go z nim więzy przyjaźni ${ }^{37}$. Argumentem za tym, że wybór mógł być jednak dokonany w Mediolanie, może być tamtejsza sytuacja ekonomiczna. Otóż Kościół mediolański czerpał dochody z majątków na Sycylii i na innych terenach pozostających nadal w ,rzeczypospolitej”38.

Papież bez wątpienia świadomie wykorzystywał w tym przypadku sytuację: skierował w kwietniu 593 r. do Genui (via Mediolan) list (III 29) do tamtejszego duchowieństwa z zapytaniem, czy wyrażają zgodę na wybór, jaki według tego, co mu doniesiono, dokonany został w Mediolanie. Zaznacza jednak, że od dawna postanowił nie stawać po niczyjej stronie, jeśli chodzi o wybór biskupa, a jedynie towarzyszyć mu modlitwą. W ten sposób postanowił uwiarygodnić

${ }^{32}$ Por. tamże XIII 12 (14).

${ }^{33}$ Por. tamże III 29, CCL 140, 174-175, Czuj I 205-206.

${ }^{34}$ Por. Markus, Grzegorz Wielki, s. 167-170.

${ }^{35}$ Podobnego zdania jest G.P. Bognetti (L'età longobarda, Milano 1966, 225, n. 67). Odmienny pogląd wyraził w uwadze do listu III 29 Ludwig Hartmann w wydaniu korespondencji Grzegorza, MGHEpist 1, 186. Za tym poglądem idą C.G. Mor (Contributi alla storia dei rapporti fra Stato e Chiesa al tempo dei Longobardi. I. La politica ecclesiastica di Autari e Agilulfo, „Rivista di storia del diritto italiano" 3 (1930) 113-114) oraz V. Rechia (Opere di Gregorio Magno, V/1: Lettere, a cura di V. Recchia, Roma 1996, 424-425, nota 1).

${ }^{36}$ Jej echo brzmi wyraźnie w tym kontekście w liście Grzegorza do Konstancjusza (Epistula IV 2) już jako biskupa, napisanym po tym, jak papież otrzymał od diakona Bonifacjusza dokładne informacje o sytuacji w Kościele mediolańskim.

${ }^{37}$ Por. Markus, Grzegorz Wielki, s. 169.

${ }^{38}$ Por. Gregorius Magnus, Epistulae XI, 6 i I 80. 
otrzymany bez podpisów list i uzyskać potwierdzenie powszechnej zgody, co do wyboru, nie angażując się pozornie po niczyjej stronie. Doręczycielem listu do duchowieństwa przebywającego w Genui był subdiakon Jan ${ }^{39}$, którego już wcześniej posłał, jako swego przedstawiciela do Mediolanu ${ }^{40}$. Grzegorz wykorzystał, jak się zdaje, okazję w delikatnej materii sukcesji po Laurencjuszu do wzmocnienia swego wpływu na Kościół w Mediolanie, zagrożony przez Longobardów. Wpływ ten wyrażał się również w gwarancjach ekonomicznych ${ }^{41}$, co mogło mieć decydujące znaczenie dla utrzymania tamtejszego duchowieństwa po stronie Rzymu. Niezależnie od tego, jak podkreśla Markus, wybór ten ujawnił całą złożoność sytuacji związanej z obsadzeniem stolicy, której duchowieństwo faktycznie było podzielone na dwa miasta: jedno z nich pozostawało pod kontrolą Longobardów, a drugie Rzymu. Pozwala to dostrzec, jak Grzegorz umacniał swoją pozycję na terenach podległych nadal cesarstwu ${ }^{42}$, a dodajmy, również na kontrolowanych już przez Longobardów.

Niezależnie od tego, ideałem wyrażanym w korespondencji Grzegorza jest dążenie do zachowania jak największej autonomii poszczególnych wspólnot w dokonywaniu wyboru biskupa. Dowodzi też tego zastrzeżenie, kierowane często w listach do biskupów pełniących urząd wizytatora w Kościołach im powierzonych po śmierci biskupa: Grzegorz napominał, aby nie pozwalali na wybór kogokolwiek z innego Kościoła, chyba że w miejscowym Kościele nie znajdzie się nikt godny biskupstwa, w co jednak, jak sam zaznacza, nie wierzy ${ }^{43}$. Była to zasada stosowana od dawna, ponieważ znajdujemy ją już wśród dekretów papieża Celestyna I (422-432) ${ }^{44}$.

Grzegorz wolał, aby szukano kandydatów na miejscu, nie tylko dlatego, że, jak wspomina w liście (602 r.) do patrycjusza Wenancjusza z Panormos:

„stąd [tzn. z Rzymu - przyp. JL] dać kapłana [na biskupa - przyp. JL] jest pod każdym względem trudno, ponieważ przytłacza nas wielka konieczność ludzi dla przydzielenia pasterzy w innych wymagających tego miejscach" ${ }^{\prime 4}$.

Równie istotną rację stanowił fakt, że niemożność dokonania wyboru biskupa $\mathrm{z}$ własnego grona, był postrzegany jako hańba dla miejscowego ducho-

\footnotetext{
${ }^{39}$ Por. tamże III 30.

${ }^{40}$ Por. tamże III 29.

${ }^{41}$ Por. tamże XI 6.

${ }^{42}$ Por. Markus, Grzegorz Wielki, s. 170.
}

${ }^{43}$ Por. Gregorius Magnus, Epistula (ad Benenatum Cumanae Ecclesiae visitatorem) II 22, CCL 140, 109: „nullum de altera eligi permittas Ecclesia, nisi forte inter clericos ipsius civitatis in qua visitationis impendis officium nullus ad episcopatum dignus, quod evenire non credimus, potuerit inveniri”. Tę samą formułę zawierają listy V 21; VI 21; VII 16; IX 81, 100 i 185; XIII 14 i 19.

${ }^{44}$ Por. Caelestinus, Epistula ad episcopos provinciae Viennensis 5, PL 50, 434B: „Tunc alter de altera eligatur Ecclesia, si de civitatis ipsius clericis cui est episcopus ordinandus nullus dignus potuerit inveniri. Primum enim illi reprobandi sunt, ut aliqui de alienis clericis merito praeferantur".

${ }^{45}$ Gregorius Magnus, Epistula XIII 12 (14), CCL 140A, 1012, przekład własny; por. Czuj IV 182. 
wieństwa ${ }^{46}$. Papież starał się w każdym przypadku znaleźć godziwe wyjście. Kiedy na przykład przez dłuższy czas nie można było znaleźć w Aprutium stosownej osoby w gronie tamtejszego duchowieństwa, Grzegorz polecił zachęcić człowieka świeckiego, który, według świadectw, odznaczał się wysokim stopniem życia religijnego, aby zechciał przyjąć najpierw tonsurę, następnie subdiakonat lub nawet zostać mnichem po to, by w odpowiednim czasie wysunąć go na urząd biskupi ${ }^{47}$.

Wybór osoby całkowicie świeckiej na biskupa odrzucał papież zdecydowanie bez względu na styl jej życia lub zasługi. Już samo staranie się świeckiego o wybór na stolicę biskupią, groziło mu pozbawieniem możliwości pełnienia dotychczasowych obowiązków i wykluczeniem od komunii ${ }^{48}$. W sprawie osób ze stanu świeckiego, sięgających po godność biskupią, interweniował nawet u królów frankońskich -Teoderyka i Teodeberta ${ }^{49}$. Uprzedzał również ewentualne próby takiego wyboru tam, gdzie podejrzewał, iż mogą one zostać podjęte ${ }^{50}$.

Procedura wyboru biskupa wymagała uprzedniego wydania opinii o życiu i obyczajach kandydata ${ }^{51}$. Zwykle zadanie to spoczywało na barkach miejscowego duchowieństwa, które najlepiej go znało. Czasem papież zlecał tę misję biskupom sąsiednich Kościołów ${ }^{52}$ lub rezydującym na miejscu swoim przedstawicielom ${ }^{53}$, albo jakiemuś zaufanemu patrycjuszowi ${ }^{54}$. Konieczność starannego zbierania informacji i prowadzenia całej procedury wyboru podyktowana była między innymi tym, że wybierający zobowiązani byli w przyszłości do posłuszeństwa wybranemu, dlatego lepiej będzie, jak podkreślał Grzegorz, jeśli już przed wyborem zostanie przez nich osądzony co do przydatności, niż później, kiedy wybrany nie może już podlegać ich sądowi ${ }^{55}$.

Ostatecznie jednak, bez względu na to, na kogo się zgodzono, wymagany był również konsensus ze strony ludu, który wyrażał swą wolę w formie aklamacji; był to wymóg ustalony tradycją, a potwierdza go już m.in. papież Leon Wielki, w którego korespondencji znajdujemy polecenie, aby nie wyświęcać żadnego biskupa bez zgody ludu ${ }^{56}$.

\footnotetext{
${ }^{46}$ Por. tamże X 19.

${ }^{47}$ Por. tamże XII 4.

${ }^{48}$ Por. tamże IX 82 i 178. Podobną formułę zawierają inne listy, np. XIII 14, 15, 18 i 19.

${ }^{49}$ Por. tamże IX 216.

${ }^{50}$ Por. np. listy IX 82; XIII 14 i 15.

${ }^{51}$ Por. tamże XI 6; XIII 15; XIV 11.

${ }^{52}$ Por. tamże IX 139; X 13; XIV 11.

${ }^{53}$ Por. tamże VII 38; zob. też list X 7, gdzie zadanie to w stosunku do Amandusa wybranego na biskupa Surrentum zostało powierzone równocześnie subdiakonowi Antemiuszowi, zarządcy dóbr kościelnych w Kampanii, oraz Fortunatowi, biskupowi Neapolu.

${ }^{54}$ Por. np. Epistula XIII 12.

${ }^{55}$ Por. tamże III 29.

${ }^{56}$ Por. Leo Magnus, Epistula 13, 3.
} 
Komplikacje związane z wyłanianiem biskupów na wakujące stolice bywały niekiedy nader poważne. Taka okazała się pod koniec VI wieku sytuacja w Neapolu, gdzie wybór biskupa przebiegał pod znakiem walki dwóch przeciwnych stronnictw. Kiedy przed wrześniem $591 \mathrm{r}$. tamtejszy biskup Demetriusz został deponowany z urzędu za „najcięższe przewinienia” - których papież wprawdzie nie wymienia, ale zaznacza, że gdyby stanął przed sądem, wymierzono by mu za nie najwyższą karę ${ }^{57}$ - Neapolitańczycy wybrali sobie Pawła, biskupa Nepe ${ }^{58}$. Papież nie zatwierdził jednak tego wyboru mianując Pawła tymczasowo tylko wizytatorem ${ }^{59}$, choć też nie odmówił mianowania go biskupem tego miasta (episcopus cardinalis) uważając prawdopodobnie, że nie ma pośpiechu w tak istotnych sprawach ${ }^{60}$; nie chciał też podejmować decyzji ze względu na samego Pawła, który nie kwapił się do zmiany stolicy biskupiej. Jak słuszne okazało się takie postępowanie, pokazała przyszłość. Paweł bowiem nie znalazł uznania u wszystkich. Ktoś nawet sprowokował przeciwko niemu bunt w leżącej pod Neapolem warowni Lucullanum ${ }^{61}$. Sprawa musiała być na tyle poważna, że poruszony papież sam postanowił interweniować. Dla zbadania sprawy i ukarania winnych posłał we wrześniu 592 r. subdiakona Epifaniusza, który miał działać wraz z sędzią Kampanii Scholastykiem ${ }^{62}$. Przykre doświadczenia spowodowały, że Paweł już na przełomie 591/592 r. postanowił wrócić do swego Kościoła w Nepe ${ }^{63}$, choć o zgodzie papieża na jego powrót dowiadujemy się dopiero z listu datowanego w maju 593 roku $^{64}$. Nowy wybór biskupa wyłonił tymczasem subdiakona Florencjusza, należącego jednak do duchowieństwa Kościoła rzymskiego, co poświadcza jeden z listów Grzegorza, mówiącego o nim „nasz subdiakon”. Ten jednak, być może, przewidując podobne trudności, jakie przeżył Paweł, postanowił ratować się przed biskupimi święceniami ucieczką (dowiadujemy się o tym z listu datowanego w grudniu 592 roku) ${ }^{65}$. Trudno oczywiście wyobrazić sobie, że nie towarzyszyło mu ciche przyzwolenie papieża, które pozwoliło Florencjuszowi uniknąć nacisków ścierających się frakcji i wchodzenia w ogień nieporozumieńn ${ }^{66}$.

Przewidując inne jeszcze trudności w wyborze biskupa, papież zaleca w przypadku takiego niepowodzenia wydelegować trzech mężczyzn uczciwych i mądrych, cieszących się zaufaniem całości, tzn. władz (priores) i ludu

\footnotetext{
${ }^{57}$ Por. Gregorius Magnus, Epistula II 3, CCL 140, 91.

${ }^{58}$ Por. tamże II 8.

${ }^{59}$ Por. tamże II 9.

${ }^{60}$ Por. tamże II 8.

${ }^{61}$ Por. tamże III 1.

${ }^{62}$ Por. tamże III 1 i 2.

${ }^{63}$ Por. tamże II 14.

${ }^{64}$ Por. tamże III 35.

${ }^{65}$ Por. tamże III 15.

${ }^{66}$ Por. J. Czuj: Św. Grzegorz Wielki, Listy, I, Warszawa 1954, s. 193, noty 2 i 3 do III 15 oraz s. 212 , noty 3 i 5 do III 35 .
} 
(populus civitatis), aby wybrali w Rzymie kogoś spośród miejscowego duchowieństwa na biskupa Neapolu ${ }^{67}$. Polecenie to ponowił papież jeszcze w maju 593 r., zgadzając się jednocześnie na powrót Pawła do Nepe ${ }^{68}$. Dwuletni wakat zakończył się wreszcie z objęciem urzędu w tym samym roku przez Fortunata ${ }^{69}$, choć i ten wybór nie doprowadził do zażegnania podziałów. Fortunat początkowo przyjęty życzliwie ${ }^{70}$, wkrótce włączył się w wir miejscowych sporów, co doprowadziło ponownie do konfliktów wśród ludności ${ }^{71}$. Spośród licznych listów papieża pisanych do niego w różnych sprawach, ostatni adresowany jest jeszcze w kwietniu 600 roku $^{72}$.

Następny list wysłany do Neapolu dotyczy już wyboru nowego biskupa po śmierci Fortunata i pochodzi z lipca tegoż roku ${ }^{73}$. Kolejne wydarzenia z tym związane pokazują, że Grzegorz rezerwował sobie prawo ingerencji w przypadku, gdy na stolicę miano by wybrać osobę niegodną lub nieznaną ${ }^{74}$. Ingerencje te nie należały, jak się wydaje, do rzadkości. Sposób postępowania przy wyborze nie był bowiem wolny od wielu wad. Jak wynika z wyżej przedstawionych przykładów, łatwo było o konflikty wywołane różnicą zdań bądź interesów. Wkrótce po śmierci Fortunata w Neapolu doszło do nowego podziału, w którym część duchowieństwa i nobilów opowiedziała się za diakonem Janem, a część za diakonem Piotrem ${ }^{75}$. Papież odrzucił możliwość wyboru któregokolwiek z nich powiadomiony, że jeden zajmował się lichwą i był prostakiem, drugi natomiast miał już małą córkę, co dowodziło, że nie panował nad popędami ciała ${ }^{76}$. Wynika stąd, że Grzegorz posiadał często informacje bardzo dokładne, i zdarzało się, że zastrzegał, iż konkretna osoba nie może zostać wybrana. Tym razem jednak udało się dokonać wyboru stosunkowo szybko, ponieważ następny list do biskupa Neapolu, którym został Paskazjusz, datowany jest już na styczeń $601 \mathrm{roku}^{77}$.

Warto zaznaczyć, że obok opisanych wyżej sposobów wybierania biskupa w metropolii rzymskiej i na Sycylii istniał również zwyczaj, że wybierano dwóch lub trzech kandydatów i wysyłano ich do papieża, aby ten spośród nich dokonał ostatecznego wyboru ${ }^{78}$. W przypadku wątpliwości, co do zdatności konkurencyjnych kandydatów, dla uniknięcia zwłoki papież nakazywał

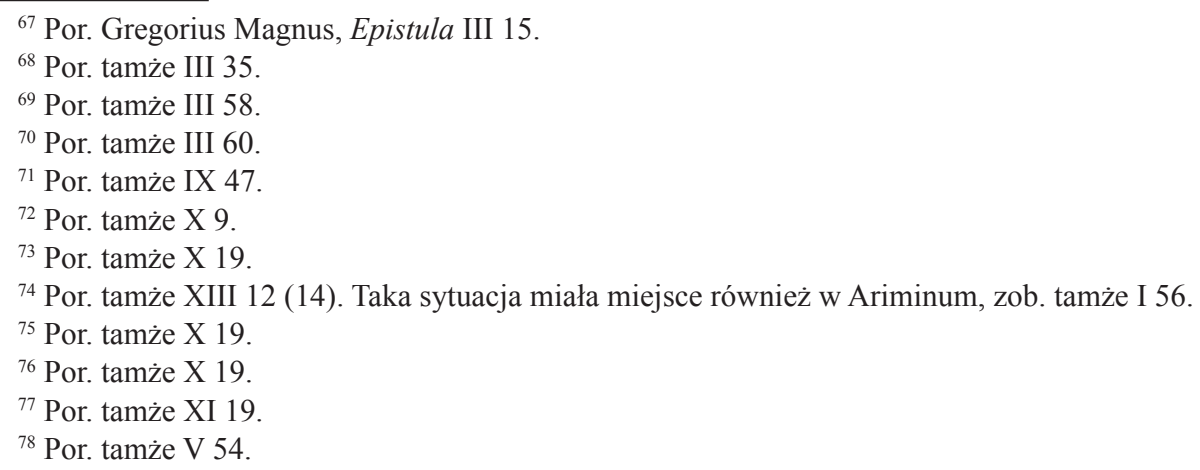


ludności przysłać ich do siebie, aby mógł sam zdecydować, którego z nich wyznaczyć na urząd biskupa ${ }^{79}$.

Po wyłonieniu kandydata w stolicy należącej do metropolii rzymskiej, papież wzywał go do siebie, aby osobiście udzielić mu święceń ${ }^{80}$. Mający je przyjąć wybrany kandydat zjawiał się z pismem informującym o dokonanym wyborze sygnowanym przez wszystkich wybierających oraz z uwierzytelniającym pismem wizytatora ${ }^{81}$. Praktyka konsekracji wybranego kandydata w Rzymie, dotyczyła głównie terenów znajdujących się pod zarządem papieża i na tyle bliskich, że jego przybycie nie wiązało się ze szczególnym trudem i zagrożeniem ze strony Longobardów lub innymi niebezpieczeństwami. Zdarzały się jednak odstępstwa od tej zasady. Tak było m.in. w przypadku Forum Cornelii (Imolae, Imoli - dzisiejsze Imola), gdzie w miejsce „upadłego biskupa” nowy biskup konsekrowany był przez biskupa Rawenny ${ }^{82}$. Zwyczajowo biskupi Mediolanu i Rawenny święcili jako metropolici swoich sufraganów ${ }^{83}$, choć $\mathrm{i}$ tu istniały pewne odstępstwa, jak np. biskup nieodległego od stolicy egzarchatu Ariminum (Rimini) konsekrowany był przez papieża, mimo iż przygotowany wywiad o nim prowadził biskup Rawenny Marynian ${ }^{84}$.

Polityka papieża przy obsadzaniu stolic biskupich opierała się na praktyce wynajdywania ludzi sprawdzonych, którzy swoim dotychczasowym życiem dowiedli swojej prawowierności. Miało to szczególne znaczenie w sytuacji, kiedy w niektórych miastach (a dotyczyło to zwłaszcza Sycylii) biskupi ${ }^{85} \mathrm{mu}-$ sieli być deponowani z powodu publicznego zgorszenia, wywołanego często niemoralnym życiem. Powodami takiej depozycji i publicznej pokuty były najczęściej odstępstwa od wiary i obyczajów, jak idololatria, herezja, schizma lub grzechy ciała. Takie zdarzenia nie należały do rzadkości, gdy Grzegorz obejmował rządy Kościołem. Jego działania jako papieża konsekwentnie zmierzały do uzdrowienia nabrzmiałych problemów przez staranną politykę personalną. Jednym z jej sposobów było wnikliwe wyszukiwanie na miejsce upadłych nowych pasterzy spośród duchowieństwa tamtejszych Kościołów lub klasztorów. Zadaniem tym obarczył papież na Sycylii swego zaufanego współpracownika, subdiakona Piotra, podówczas zarządcę majątku Kościoła rzymskiego ${ }^{86}$. W przypadku braku odpowiedniego kandydata papież, jak się

\footnotetext{
${ }^{79}$ Por. tamże XIII 12.

${ }^{80}$ Por. tamże I 18; VII 38; X 7, 13 i 18.

${ }^{81}$ Por. tamże XIII 19; VII 38.

${ }^{82}$ Por. tamże VII 39.

${ }^{83}$ Por. np. tamże VII 39.

${ }^{84}$ Por. tamże IX 139.

${ }^{85}$ Por. tamże I 18. Grzegorz używa tu słowa sacerdos. Kontekst wskazuje jednoznacznie, że chodzi o biskupów. Często bowiem sacerdos w Listach Grzegorza oznacza biskupów.

${ }^{86}$ Por. tamże I 18. Na temat Piotra dowiadujemy się z licznych listów do niego skierowanych. Zanim objął zarząd majątku na Sycylii znajdujemy go na stanowisku defensora w Rawennie, zob. tamże VI 24. List do biskupa Rawenny z lipca 693 r. określa go już jako diakona, zob. tamże III
} 
wydaje, sam wyznaczał kogoś ze znanych sobie duchownych, aby nie pozostawiać zbyt długo poszczególnych miejscowości bez biskupów, jak również przeciąc ewentualne nadzieje i próby powrotu upadłych na dawne stanowisko $^{87}$. Zgodnie bowiem z przyjętym obyczajem, duchowny, który dopuścił się jakiegoś crimen, nie mógł powrócić na piastowane wcześniej stanowisko.

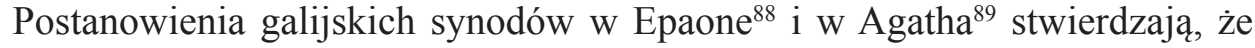
biskup, prezbiter lub diakon, którzy dopuścili się jakichś poważnych przestępstw, sfałszowali dokument albo fałszywie świadczyli, złożeni z urzędu winni być oddaleni do klasztoru, i tam, jak długo żyć będą, winni otrzymywać komunię jedynie jak laicy ${ }^{90}$.

Inną z bolączek, jakie doskwierały Kościołowi, kiedy Grzegorz obejmował stolicę św. Piotra, była symonia. Jego bezwzględne stanowisko w odniesieniu do tej praktyki wykluczało absolutnie winnych tego przestępstwa $\mathrm{z}$ posługi kościelnej ${ }^{91}$. W swoich listach wielokrotnie zastrzegał, że wszelkie procedury związane z wyborem na biskupa muszą się dokonywać z wykluczeniem jakiejkolwiek możliwości kupna tego urzędu². Uderza nas zwłaszcza jego uporczywe zwracanie uwagi na ten problem w korespondencji z królami i biskupami krajów frankońskich. Wydaje się, że był to ważny element kształtowania i zachowywania autonomii Kościoła.

Jeśli jednak papież był spokojny o rzetelność przeprowadzonych wyborów, starał się w nie sam już nie ingerować. Tak na przykład w liście do Kościoła mediolańskiego z kwietnia 593 r. wyraził swoją postawę wynikającą, jak to określił, z długiego namysłu, aby nie mieszać się w elekcję nowego biskupa stając po czyjejkolwiek stronie ${ }^{93}$. Starał się tej zasady trzymać zawsze tam, gdzie był spokojny o wynik wyboru, albo tam, gdzie jakakolwiek interwencja

54. W czasie indykcji IX i X był zarządcą majątku kościelnego na Sycylii pełniąc równocześnie w czasie indykcji IX funkcję wikariusza apostolskiego na wyspie, zob. tamże I 9, 18, 39, 42, 44, 54, 65, 67, 69, 70 i 71). Listem z przełomu lipca i sierpnia 592 r. (zob. tamże II 50) papież wezwał sycylijskiego subdiakona Piotra do Rzymu. Później kierował do niego listy do Kampanii (zob. tamże III 1, 5, 19, 23, 34, 35 i 39), gdzie znów zarządzał majątkiem kościelnym. Wreszcie Piotr, jak wynika z listu IX 11, został sekretarzem papieża; por. też Lettere, ed. V. Recchia, w: Opere di Gregorio Magno, V/1, Roma 1996, s. 107, n. 1; s. 372-373, n. 1; A. de Vogüé, Introduction, w: Grégoire le Grand, Dialogues, SCh 251, 44-46 i 79-80 oraz SCh 260, 10.

${ }^{87}$ Por. Gregorius Magnus, Epistula I 18.

${ }^{88}$ Por. Concilium Epaonense (517) can. 22, CCL 148A, 29.

${ }^{89}$ Por. Concilium Agathense (506) can. 50, CCL 148, 225.

${ }^{90} \mathrm{O}$ konieczności obsadzania stolic po upadłych biskupach por. np. Gregorius Magnus, Epistula VII 14 i 39.

${ }^{91}$ Por. tamże V 24.

${ }^{92}$ Por. np. tamże IV 13; V 16, 58, 60, 62 i 63; VI 3, 7 i 26; VIII 4; IX 136, 156, 178 i 179; IX 214, 216, 219 i 220; XI 28, 38, 42, 47, 49 i 51; XII 8 i 9; XIII 44.

${ }^{93}$ Por. tamże III 29, CCL 140, 174: „Verumtamen quia antiquae meae deliberationis intentio est ad suscipienda pastoralis curae onera, pro nullius unquam misceri persona, orationibus prosequor electionem vestram, ut omnipotens Deus, qui futurorum actuum nostrorum semper est praescius, 
mogła przynieść więcej szkody niż pożytku. Notatka zawarta w liście do diakona Cypriana w sprawie wyboru biskupa w Syrakuzach świadczy jednak, że starał się przez swoich przedstawicieli wpływać na wybór w sposób pozytywny, jeśli widział dobrego kandydata wywodzącego się z miejscowego środowiska: nakazywał wówczas objęte tajemnicą dodatkowe badanie kandydata. I w takim przypadku pozostawiał ostatecznie możliwość wyboru innej osoby, niż sam uprzednio oczekiwał.

Wyborów zalecał dokonywać rychło, aby Kościoły nie pozostawały zbyt długo bez rządców ${ }^{94}$. Trzymając się starej zasady, że według kanonów stolica biskupia nie powinna wakować dłużej niż trzy miesiące ${ }^{95}$, Grzegorz odwoływał się do tradycyjnego prawodawstwa. Termin taki przepisywał bowiem Sobór Chalcedoński ${ }^{96}$, a także Kanony Apostolskie ${ }^{97}$, synod w Kartaginie z 419 r. $^{98}$ (kanony 71, 74, 78, 121,123, 124) Novellae Justyniana ${ }^{99}$. Zdarzało się bowiem, że musiał czasem interweniować w przypadkach, gdy metropolici zwlekali z wyświęceniem nowo wybranego biskupa, jak to miało miejsce np. w Cornelium, podległym Rawennie ${ }^{100}$.

$$
* * *
$$

Grzegorz Wielki miał świadomość, że wybory biskupów mają podstawowe znaczenie dla życia Kościoła. Wszystkie jego interwencje w tej sprawie miały na celu zapewnienie obejmowania stolic biskupich przez kandydatów godziwych, to znaczy cieszących się dobrą sławą, prowadzących nienaganne moralnie życie oraz posiadających konieczną wiedzę w zakresie Pisma Świętego i doktryny katolickiej. Służyły temu celowi przede wszystkim procedury, jakie starał się wprowadzać i stosować. Polegały one między innymi na przeprowadzaniu procesu informacyjnego w odniesieniu do kandydata, jak i włączaniu w jego wybór miejscowego duchowieństwa oraz ludności. Według papieża do posługi biskupiej można było przeznaczać tych, którzy o nią nie zabiega$1 i^{101}$. Polityka, jaką stosował papież przy obsadzaniu biskupów, miała na celu zacieśnianie ich więzów ze Stolicą Apostolską. Miało to ogromne znaczenie w sytuacji destrukcji instytucji i struktur państwowych w zachodniej Italii oraz zagrożenia tradycyjnego porządku przez Longobardów. Polityka ta zmierza-

\footnotetext{
talem vobis pastorem praebeat, in cuius lingua et moribus exhortationis divinae pascua valeatis invenire", zob. Czuj I 206.

${ }^{94}$ Por. tamże I 78; II 3; III 35; VII 14; III 35.

${ }^{95}$ Por. tamże VII 39; VII 14.

${ }^{96}$ Por. Concilium Chalcedonense can. 25, ŹMT 24 (= DSP 1), 247.

${ }^{97}$ Por. Por. Canones Apostolorum can. 58, ŹMT 42 (= SCL 2), 287.

${ }^{98}$ Por. Concilium Carthaginiense (419) can. 71, 74, 78, 121, 123, 124, CCL 149, 201-228.

${ }^{99}$ Por. Justiniani Novellae 123, PL 72, 1022-1024.

${ }^{100}$ Por. Gregorius Magnus, Epistula VII 39.

${ }^{101}$ Por. tamże VII 5; IX 219.
} 
ła w równym stopniu do wykluczenia manipulacji w sprawach Kościoła ze strony osób świeckich. Przejawiało się to między innymi w uniemożliwieniu przyjęcia biskupstwa przez osobę świecką, nie należącą do duchowieństwa. W przypadkach trudności z wyborem nowego biskupa Grzegorz sam wyznaczał osoby proponowane $\mathrm{z}$ grona miejscowego prezbiterium lub spośród własnego duchowieństwa rzymskiego. W każdym razie papież rezerwował sobie prawo do zatwierdzania wyboru biskupów ${ }^{102}$.

\section{EPISCOPAL ELECTIONS IN THE LIGHT OF THE CORRESPONDENCES OF POPE GREGORY THE GREAT}

\section{(Summary)}

Having presented briefly the context in which the Church found herself, as well as the criteria required of candidates to episcopacy, the author discusses problems related to the promotion of bishops, based on selected examples extracted from the correspondences of Pope Gregory the Great. It shows that His Holiness was aware of the significant role played by episcopal elections in the Church's life. His interventions in this matter were to ensure that local sees were assigned to appropriate candidates, i.e. those of good reputation, outstanding in good morals and possessing the expertise required in Sacred Scriptures and Catholic doctrines. Procedures implemented by Pope Gregory the Great with the aim of achieving this goal involved, amongst other things gathering information about the candidates to the episcopacy as well as the inclusion of the entire local clergy and all the lay faithful in the electoral process. Such a policy undertaken by His Holiness in promoting episcopates was aimed at strengthening their ties with the Holy See. This proved to be influential, especially during the institutional and structural destruction in Western Italia and threats from the Lombards, who wanted to destroy the well-established traditional Roman order. To avoid all forms of manipulation by lay persons in ecclesiastical matters, this policy excluded the possibility of promoting a layman to the episcopacy. Where there were difficulties in solving electoral issues, Gregory the Great often personally appointed candidates from the local clergy or from the Roman clergy. Pope Gregory the Great also reserved the right of preconisation of the elected bishops.

\footnotetext{
${ }^{102}$ Por. tamże III 46.
} 
